\title{
The Effect of Blended Learning on Reading Interest Through Group Counseling
}

\author{
Rasimin* \\ Departement Guidance and counseling \\ Jambi of Universty \\ Jambi, Indonesia \\ Rasimin.fkip@unja.ac.id*
}

\author{
Affan Yusra \\ Departement Guidance and counseling \\ Jambi of Universty \\ Jambi, Indonesia \\ affan15yusra@unja.ac.id
}

\begin{abstract}
This study aims to: 1) Describe the interest in reading through the group procedure course in counseling for guidance and counseling students faculty of occurrence and education science jambi university class of 2017/2018. 2) Describe the blended approach in the group procedure course in counseling to the students of the Faculty of Law class of 2017/2018. 3) Describe the effect of the blended learning method on the interest in reading through group procedure courses in counseling for bimbingan and conceling faculty of occurrence and education science jambi university class of 2017/2018. This type of research is quantitative research with Exfo-facto research design, ex post facto research. For the hypothesis in this study using a simple regression test with a significance level of 0.050, . Tcount is 9,886 at the significant level of 0,000 . And the ttable calculation result is 1,225 , so $t$ arithmetic $\square \mathrm{t}$ table then $\mathrm{Ho}$ is rejected, meaning that the regression coefficient is significant. It can be concluded that blended learning has an effect on the reading interest of students of the 2017/2018 BK Force.
\end{abstract}

Keywords- blended learning method, interest in reading

\section{INTRODUCTION}

Reading is an activity in the form of seeing and understanding the contents of the text being read. With frequent reading activities carried out by individuals, it will increase their knowledge, but also will draw closer to the creator. But at this time reading activities in the world, especially in developing countries, one of which Indonesia tends to be less attractive to individuals, this is caused by several things as follows; very rapid technological developments, facilities and infrastructure, costs and education levels of this data obtained from the results of a survey conducted by UNESCO in 61 countries in 2017 the country of Indonesia was in the 60th position.

As shown in the results of the following research; [1] in his research stated that the causes of low interest in reading include experience, self-concept, values, the significance of the field of study, individual differences, the level of obligation to be involved, and the suitability of the field of study. [2] in his research shows that the low interest in reading is reviewed in terms of suggestions and infrastructure.
Interest in reading is a strong desire to do the reading activity from someone without any coercion from others. Interest in reading is an encouragement arising from within yourself to read [3]. interest in reading is a motivation from within a very strong individual that will be realized in his willingness to look for and then read it [4]

Some forms of low interest in reading in some students of FKIP UNJA in semester 4 of the 2017/2018 academic year are students who are lazy to read books, want instant ones from Google, low desire to learn, copy their friends' assignments in studying or examinations. In this case, the interest in reading can also be influenced by the method of learning, one of them is the blanded learning method.

Blanded learning which is also known as hybrid learning is a learning method that combines face-to-face and computer-based learning [5]. The position of the blended learning approach in the learning process as expressed is as follows: a) Face to face; b) M-Learning; c) e-learning [3]. Revealed from the results of his research that the blanded learning approach can contribute to pharmacy students in their activities in learning [6]. showed the method of blended learning in group discussions in learning can foster positive relationships and be able foster positive learning outcomes [7].

Refer to the results of surveys, grand theories and research relevant to this problem. the researcher is interested in examining this issue with the title "The Effect of Using the Blended Learning Method on Interest in Reading Through Group Procedures in Counseling Subjects for Students of Guidance and Counseling FKIP UNJA $2017 / 2018$. The main objective in this research is to reveal the effect of using the Blended learning approach in increasing student reading interest. Furthermore, the specific objectives of this research are to: 1) Describe the interest in reading through the group procedures in counseling courses for students of the Faculty of Teacher Training and Education Faculty of UNJA class of 2017/2018. 2) Describe the blended approach in the group procedure course in counseling to the students of the Faculty of Law class of 2017/2018. 3) Describe the effect of the blended learning method on the interest in reading through group procedure courses in counseling for the students of the FK FKIP UNJA 2017-2018 class. 


\section{METHODS}

This type of research is quantitative research with Exfo-facto research design, ex post facto research or afterfact research is a research design category in which the investigation begins after the fact occurs without interference from the researcher. The majority of social research, in contexts where it is impossible or not acceptable to manipulate the characteristics of human participants, is based on an ex post facto research design. It is also often applied as a substitute for true experimental research to test hypotheses about cause-effect relationships or in situations where it is not practical or ethically acceptable to apply the full protocol of a true experimental design. Despite studying the facts that have taken place, ex-post facto research shares with experimental research designs some of the basic logic of the Brog and Gall investigation [8].

Research subjects are people who decide to participate in research [9]. This is completely voluntary. You help the researcher see the questions he wants to learn. researched are located and observed by researchers as for the samples in this study were students of the FKIP UNJA BKIP Angakatan 2017/2018. Its position is very central then in the sampling technique using a purposive sampling method, Purposive sample is a non-probability sample selected based on population characteristics and research objectives. Purposive sampling is also known as judgmental, selective, or subjective sampling [10].

The instrument used in research that is the ratio scale is the highest level of measurement and is not often available in social research. The factor that clearly defines the ratio scale is that it has a correct zero point, as Azwar explains the scale will be a question or statement expressing the behavioral indicators of the attribute in question. The use of scales is based on factual data felt by subjects based on predetermined indicators [11].

Furthermore, in the process of the instrument to be given that is related to reading interest, namely the reading interest scale, in this study the scoring that will be used is the Likert scale model with a frequency scale consisting of Always (SL), Often (S), Sometimes (KK) , Rarely (J) and Never (TP). For more details can be seen in the following table.

Data collection techniques in this research use a questionnaire (questionnaire) Questionnaire is part of a research tool consisting of a series of questions for the purpose of gathering information from respondents [12]. Questionnaire (Questionnaire) is used to obtain research data related to the effect of the use of the 'learning method on the interest in reading students of FK FKIP UNJA force.

Data analysis is the process of systematically searching and compiling data obtained from interviews, field notes, and documentation to group data so that it is easily understood by oneself and others. This study includes quantitative research whose data analysis is directed at answering problem formulations or testing hypotheses that have been formulated by statistical methods.

Statistics that function to describe or provide an overview of the object under study through sample data or population as it is, without conducting analysis and making general conclusions. In descriptive statistics used to describe data or determine the central tendency which includes the calculation of the mean or mean (M), mode (Mo), Median (Me), and standard deviation (SD), frequency and histogram of each variable.

The data analysis technique used is parametric analysis technique because the type of data being analyzed is interval and ratio data. Where in simple linear regression analysis techniques that are parametric to determine the effect of the independent variable $(\mathrm{X})$ on the variable $(\mathrm{Y})$ and the magnitude of the influence of the independent variable $(\mathrm{X})$ on the variable $(\mathrm{Y})$ with a simple linear regression equation used as a hypothesis test.

\section{RESULT AND DICUSSION}

Result

The results of data processing on the variable reading interest of the whole sample (respondents) numbered $40 \mathrm{BK}$ students, most of the BK students' reading interests were in the moderate category with a total frequency of 32 students or $80 \%$ could be presented. Whereas with the less category the number of frequencies was 8 students or could be presented at $20 \%$. And for the category of very good and low frequency obtained zero or zero value of all respondents can be seen in table 1 .

Table 1. Description of Average (Mean) and Percentage (\%) of blended learning Based on Indicators

\begin{tabular}{|c|c|c|c|c|c|c|c|}
\hline \multirow[b]{2}{*}{$\begin{array}{c}\text { Varia- } \\
\text { ble }\end{array}$} & \multirow[b]{2}{*}{ Indicator } & \multicolumn{5}{|c|}{ Score } & \multirow[b]{2}{*}{ Info. } \\
\hline & & $\begin{array}{l}\text { Ide } \\
\text {-al }\end{array}$ & $\begin{array}{l}\text { The } \\
\text { High- } \\
\text { est }\end{array}$ & $\begin{array}{l}\text { The } \\
\text { Low } \\
\text {-est }\end{array}$ & Total & $\begin{array}{l}\text { Ave- } \\
\text { rage }\end{array}$ & \\
\hline \multirow{3}{*}{  } & $\begin{array}{c}\text { Face to } \\
\text { face (12) }\end{array}$ & 41 & 41 & 24 & 13361 & 33,4 & $\begin{array}{l}\text { Mode- } \\
\text { rate }\end{array}$ \\
\hline & $\begin{array}{c}\mathrm{e}- \\
\text { learning } \\
(8)\end{array}$ & 26 & 26 & 7 & 637 & 15,9 & Low \\
\hline & $\begin{array}{c}\mathrm{m}- \\
\text { learning } \\
(12)\end{array}$ & 43 & 43 & 28 & 1374 & 34,4 & High \\
\hline \multicolumn{2}{|c|}{ Total (32) } & $\begin{array}{c}10 \\
4\end{array}$ & 104 & 62 & 3347 & 83,675 & High \\
\hline
\end{tabular}

Furthermore Based on the indicators of interest in reading obtained results:

1. On the indicator of reading pleasure the results obtained from the whole sample (respondents) amounted to 40 BK students, the indicator of reading pleasure is in the medium category with a total frequency of $20 \mathrm{BK}$ students or $50 \%$ can be presented. Furthermore, it was followed in the less category with a total frequency of 14 BK students or could be presented at $35 \%$, and was in the high category with a frequency of $6 \mathrm{BK}$ students or $15 \%$ could be held, while the low category obtained zero or zero frequency frequencies from all respondents can be seen in table 2 . 
Table 2. Frequency Distribution and Score Category Feelings of reading pleasure $(n=40)$

\begin{tabular}{|c|l|c|c|}
\hline $\begin{array}{c}\text { Interval } \\
\text { Score }\end{array}$ & Category & Frequency $(\mathrm{F})$ & Percentage (\%) \\
\hline$>13$ & High & 6 & $15 \%$ \\
\hline $12-10$ & Moderate & 20 & $50 \%$ \\
\hline $9-7$ & Less & 14 & $35 \%$ \\
\hline$<7$ & Low & 0 & 0 \\
\hline \multicolumn{2}{|c|}{ Total } & 40 & 100 \\
\hline
\end{tabular}

2. On the indicator of the need for reading the results obtained from the whole sample (respondents) amounted to $40 \mathrm{BK}$ students, the indicator of the need for reading is in the moderate category and with a total frequency of $20 \mathrm{BK}$ students or can be percentaged $50 \%$. Whereas in the high and low categories with zero or zero total frequency of all respondents can be seen in table 3 [13].

Table 3. Frequency Distribution and Category Score needs for reading $(n=40)$

\begin{tabular}{|c|c|c|c|}
\hline $\begin{array}{c}\text { Interval } \\
\text { Score }\end{array}$ & Category & Frequency $(\mathrm{F})$ & Percentage $(\%)$ \\
\hline$>23$ & High & 0 & 0 \\
\hline $22-18$ & Moderate & 20 & 50 \\
\hline $17-13$ & Less & 20 & 50 \\
\hline$<13$ & Low & 0 & 0 \\
\hline \multicolumn{2}{|c|}{ Total } & 40 & 100 \\
\hline
\end{tabular}

3. On the indicator of interest in reading from the whole sample (respondents) totaling $40 \mathrm{BK}$ students, the indicator of interest in reading is in the moderate category and is lacking in the frequency of $20 \mathrm{BK}$ students or can be percentaged $50 \%$. Whereas for the high and low categories the frequency is zero or zero value of all respondents in table 4.

Table 4. Frequency Distribution and Category of interest in reading $(\mathrm{n}=40)$

\begin{tabular}{|c|c|c|c|}
\hline $\begin{array}{c}\text { Interval } \\
\text { Score }\end{array}$ & Category & Frequency $(\mathrm{F})$ & Percentage $(\%)$ \\
\hline$>19$ & High & 0 & 0 \\
\hline $18-14$ & Moderate & 20 & 50 \\
\hline $13-9$ & Less & 20 & 50 \\
\hline$<9$ & Low & 0 & 0 \\
\hline \multicolumn{2}{|c|}{ Total } & 40 & 100 \\
\hline
\end{tabular}

4. In the reading intention indicator of the total sample (respondents) totaling $40 \mathrm{BK}$ students, the reading intention indicator is in the medium category with a frequency of $22 \mathrm{BK}$ students or $55 \%$ can be presented. Furthermore, it was followed in the less category by the number of frequencies of $18 \mathrm{BK}$ students or $45 \%$ in percentage, while for the high and low categories the frequency was zero or zero value of all respondents in table 5 .
Table 5. Frequency Distribution and Reading Desire Score Categories $(n=40)$

\begin{tabular}{|c|l|c|c|}
\hline $\begin{array}{c}\text { Interval } \\
\text { Score }\end{array}$ & Category & Frequency $(\mathrm{F})$ & Percentage $(\%)$ \\
\hline$>23$ & High & 0 & 0 \\
\hline $22-18$ & Moderate & 22 & 55 \\
\hline $17-13$ & Less & 18 & 45 \\
\hline$<13$ & Low & 0 & 0 \\
\hline \multicolumn{2}{|c|}{ Total } & 40 & 100 \\
\hline
\end{tabular}

5. On the indicator of the desire to look for reading material from the whole sample (respondents), there are $40 \mathrm{BK}$ students on this indicator, the indicator of the desire to look for reading material is in the medium category with a frequency of $30 \mathrm{BK}$ students or $75 \%$ can be presentable. Furthermore, it was followed in the high category with a frequency of $7 \mathrm{BK}$ students or it could be presented at $17.5 \%$, it was in the category of seats with a frequency of $3 \mathrm{BK}$ students or it could be $7.5 \%$. Whereas for the low category the zero frequency or zero value of all respondents can be seen in table 6 .

Table 6. Frequency and Category Distribution Desire scores looking for reading material $(n=40)$

\begin{tabular}{|c|c|c|c|}
\hline $\begin{array}{c}\text { Interval } \\
\text { Score }\end{array}$ & Category & Frequency (F) & Percentage (\%) \\
\hline$>19$ & High & 7 & 17,5 \\
\hline $18-14$ & Moderate & 30 & 75 \\
\hline $13-9$ & Less & 3 & 7,5 \\
\hline$>9$ & Low & 0 & 0 \\
\hline \multicolumn{2}{|c|}{ Total } & 40 & 100 \\
\hline
\end{tabular}

6. While the results of data processing through instruments on the blanded learning variable of the total sample (respondents) totaling 40 students were obtained, most of the blended learning variables were in the medium category with a frequency of 22 BK students or $55 \%$ can be presentable. Furthermore, it was followed in the less category by the number of frequencies of $18 \mathrm{BK}$ students or $45 \%$ in percentage, while for the high and low categories the frequency was zero or zero value of all respondents in table 7 . The details can be described as follows:

Table 7. Description of Average (Mean) and Percentage $(\%)$ of blended learning Based on Indicators

\begin{tabular}{|c|c|c|c|c|c|c|c|}
\hline \multirow[b]{2}{*}{$\begin{array}{l}\text { Varia- } \\
\text { ble }\end{array}$} & \multirow[b]{2}{*}{$\begin{array}{l}\text { Indica- } \\
\text { tor }\end{array}$} & \multicolumn{5}{|c|}{ Score } & \multirow[b]{2}{*}{ Info } \\
\hline & & Ideal & $\begin{array}{l}\text { The } \\
\text { High } \\
\text {-est }\end{array}$ & $\begin{array}{c}\text { The } \\
\text { Low- } \\
\text { est }\end{array}$ & Total & $\begin{array}{l}\text { Ave- } \\
\text { rage }\end{array}$ & \\
\hline \multirow{3}{*}{ 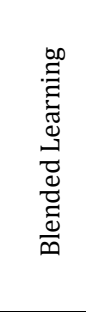 } & $\begin{array}{l}\text { Face to } \\
\text { face } \\
(12)\end{array}$ & 41 & 41 & 24 & 13361 & 33,4 & Moderate \\
\hline & $\begin{array}{c}\mathrm{e}- \\
\text { learnin } \\
\mathrm{g}(8)\end{array}$ & 26 & 26 & 7 & 637 & 15,9 & Low \\
\hline & $\begin{array}{c}\mathrm{m}- \\
\text { learnin } \\
\mathrm{g}(12)\end{array}$ & 43 & 43 & 28 & 1374 & 34,4 & High \\
\hline \multicolumn{2}{|c|}{ Keseluruhan (32) } & 104 & 104 & 62 & 3347 & $\begin{array}{c}83,6 \\
75\end{array}$ & High \\
\hline
\end{tabular}


In the face to face indicator of the total sample (respondents), there were $40 \mathrm{BK}$ students, the face to face indicator was a face to face indicator in the medium category with a total frequency of 31 students or $77.5 \%$ could be presented. Furthermore, it was followed in the less category with a total frequency of $7 \mathrm{BK}$ students or could be presented at $17.5 \%$, and was in the high category with a frequency of $2 \mathrm{BK}$ students or $5 \%$ could be held, while for the low category the frequency obtained was zero or zero value of all respondents can be seen in table 8 .

Table 8. Distribusi Frekuensi dan Kategori Skor face to face $(n=40)$

\begin{tabular}{|c|c|c|c|}
\hline $\begin{array}{c}\text { Interval } \\
\text { Score }\end{array}$ & Category & Frequency $(\mathrm{F})$ & Percentage (\%) \\
\hline$>37$ & High & 2 & 5 \\
\hline $36-26$ & Moderate & 31 & 77,5 \\
\hline $25-15$ & Les & 7 & 17,5 \\
\hline$<15$ & Low & 0 & 0 \\
\hline \multicolumn{2}{|c|}{ Total } & 40 & 100 \\
\hline
\end{tabular}

In the learning indicator indicators of the total sample (respondents) totaling $40 \mathrm{BK}$ students, the E-learning indicator is in the high category with a frequency of $30 \mathrm{BK}$ scholarship students or $75 \%$ can be presented. Furthermore, it was followed in the medium category with a frequency of $10 \mathrm{BK}$ students or $25 \%$ could be presented. Whereas for the low and low categories the zero frequency or zero value of all respondents can be seen in Table 9 .

Table 9. Distribusi Frekuensi dan Kategori Skor e-learning $(n=40)$

\begin{tabular}{|c|c|c|c|}
\hline $\begin{array}{c}\text { Interval } \\
\text { Score }\end{array}$ & Category & Frequency (F) & Percentage (\%) \\
\hline$>25$ & High & 30 & 75 \\
\hline $24-18$ & Moderate & 10 & 25 \\
\hline $17-11$ & Les & 0 & 0 \\
\hline$<11$ & Low & 0 & 0 \\
\hline \multicolumn{2}{|c|}{ Total } & 40 & 100 \\
\hline
\end{tabular}

In the m-learning indicator of the total sample (respondents), there are $40 \mathrm{BK}$ students, most of the mlearning indicators are in the medium category with a total frequency of $30 \mathrm{BK}$ students or $75 \%$ can be presented. then followed by the less category with the number of frequencies of $6 \mathrm{bk}$ students or can be presented at $15 \%$, and are in the high category with a frequency of 4 bk students or $10 \%$ can be presented. while for the low category the zero frequency or zero value of all respondents can be seen in table 10 .

Table 10. Distribusi Frekuensi dan Kategori Skor Penilaian $(n=51)$

\begin{tabular}{|c|c|c|c|}
\hline $\begin{array}{c}\text { Interval } \\
\text { Score }\end{array}$ & Category & Frequency (F) & Percentage (\%) \\
\hline$>37$ & High & 4 & 10 \\
\hline $36-26$ & Moderate & 30 & 75 \\
\hline $25-15$ & Les & 6 & 15 \\
\hline$<15$ & Low & 0 & 0 \\
\hline \multicolumn{2}{|r|}{ Total } & 40 & 100 \\
\hline
\end{tabular}

While the results of testing the hypothesis obtained after testing the analysis requirements are done and it turns out that all the scores of each study variable meet the requirements for further statistical testing, then the next hypothesis testing is carried out. The research hypothesis in this study is the effect of blended learning $(\mathrm{x})$ on reading interest $(\mathrm{Y})$.

Correlation analysis of blended learning with interest in reading produces a correlation coefficient of rxy $=$ 0.471 . with $\mathrm{r}$ table of 0.186 , which shows the correlation coefficient between blended learning with reading interest. $\mathrm{R}$ Square value of 0.034 . This shows that $3.4 \%$ of the effect of blended learning on reading interest. With the results of the hypothesis calculation Calculating the value of the table, according to Siregar the value of the table can be searched using the $t$ distribution table by means of a significant level $\alpha=0.05 / 2=0.025$ (two sides) [14]. Then look for the table in the distribution of student with the terms $\mathrm{db}=\mathrm{n}-2, \mathrm{db}$ $=40-2=38$. So that $t_{-}((\alpha, d b))=t_{-}((0.025 .38))$ is 1,225 tcount is 9,886 at the significant level of 0,000 . And the calculation result of $t$ table is 1,225 , so $t$ count itung $t$ table then Ho is rejected, meaning that the regression coefficient is significant. It can be concluded that blended learning influences the reading interest of BK students.Based on the test results that have been described, it is proven that blended learning affects the reading interest of BK students. In the following sections, the discussion for each of the variables examined in the study will be explained.

\section{Interest in reading}

The results of the descriptive analysis showed that the interest in reading BK students as a whole was in the medium category. One of the main factors being interest in reading BK students is that those who have an interest in reading on $\mathrm{BK}$ students.

Based on the results found, students who have an interest in reading can be influenced by blended learning methods. In the course group procedures in BK have applied a long time applying the blended learning method. One of them in this subject is often combining face-to-face learning with laptop media as one of the media presentation facilities in learning. Based on the results of research conducted [2] revealed the results of his research, interest in reading is the desire to carry out reading activities without coercion from others. Furthermore [12] expressed interest in reading is motivation that comes from within an individual who is realized with his own desire to read.

Based on the above research exposure, this proves that the blended learning method can make students more active in learning and reading. Interest in reading can be influenced by several things as expressed [13] while the factors that affect reading interest are influenced by two: a) Internal factors are factors that affect the individual. Factors which include physical and psychological. Physical factors are influenced by physical health while psychological factors consist of intelligence, attention, motivation and maturity. b) External factors are factors that affect the individual from the outside. Factors include, family, playmates, campus environment, economic conditions, and facilitie. 
Learning as a learning method provided by lecturers

Based on the analysis results it is known that blended learning used as a learning method is in the high category with a score of 34.4 one of the main factors causing the blended learning method in the moderate category. This reveals that the blended learning method is a combination of face-to-face and online learning [15]. Based on the findings during the use of this method, lecturers often illustrate both direct and indirect modeling.

The characteristics of blended learning refer to the definition [3], namely learning that combines synchronous and asynchronous learning settings appropriately to achieve learning objectives, then the characteristics of the blended learning model with a constructive approach have two learning settings namely: synchronous and asynchronous learning. From the findings it can be concluded that learning with blended learning has been carried out in accordance with its characteristics.

The effect of blended learning on interest in reading BK students

Blended learning the results of this study are in line with the results of research conducted [3], namely learning that combines synchronous and asynchronous learning arrangements for the use of learning objectives, the blended learning model of learning with constructive development (constructive approach) has two learning settings namely: learning synchronous and asynchronous. From the findings, it can be concluded that learning with blended learning has been carried out in accordance with its characteristics.

But the good thing is that blended learning does not become a major factor influencing the reading interest of BK students. Hoping there will be another $96.6 \%$ of other factors that attract interest in reading BK students. As view [13] : 1) Internal factors are factors that are influenced from within the individual. The loading factors, physical and psychological. Physical factors are physical factors, while psychological factors consist of intelligence, attention, motivation and maturity. 2) External factors are factors that affect the individual from the outside. Factors that include, family, playmates, campus environment, economic conditions, and facilities.

This is contrary to the findings of research conducted [4] The era of "digital literacy" is a question about the questions asked. This study discusses how to read and read various reading modes and various reading goals. Findings showing interest in reading are best represented by subcomponents of the psycho-behavioral dimension. The high level factor structure shows the general factors of reading in the order of three levels and the five second order factors representing reading in print settings, reading online, reading social media, academic reading, and recreational reading. We read with implications for future research on the psychological significance of readings.

The results of research conducted by research conducted [16] are as follows: This research underscores the importance of interest in reading in one's learning process and analyzes different opportunities. that influenced them and their breadth. It emphasizes the important features of independent factors and variables that function as correlates.

The results of the analysis prove the influence of blended learning $(\mathrm{X})$ on the reading interest of BK (Y) students. This finding was obtained based on a collection of data analysis which showed that the contribution of blended learning to the reading interest of BK students was $3.4 \%$. This shows the hypothesis which states that blended learning significantly contributes to the interest in reading BK students accepting the truth. This shows the higher blended learning received by $\mathrm{BK}$ students will tend to interest in reading $\mathrm{BK}$ students.

\section{CONCLUSION}

Based on the findings and discussion of the results of the research conclusions can be made as follows: 1) Description of the reading interest of students in the class of $2017 / 2018$, on average the overall reading interest of students of the class of 2017/2018 is in the medium category. 2) The description of the blended learning approach used by lecturers on average the overall reading interest of students in the class of 2017/2018 is in the medium category. 3) The description found that the blended learning approach contributes significantly to the reading of 2017/2018 students.

\section{REFERENCE}

[1] Khasanah, Rofiqul. 2015. Faktor-Faktor Yang Mempengaruhi Minat Membaca Siswa Kelas Iv B Sd Negeri Ngoto Sewon Bantul Tahun Ajaran 2014/2015. Universitas Negeri Yogyakarta. https://eprints.uny.ac.id/27231/

[2] Wakijo, N. (2017). Pengaruh Pemanfaatan Perpustakaan Sekolah dan Minat Baca Siswa Terhadap Hasil Belajar IPS Terpadu Siswa Kelas VII Semester Genap. https://jurnalmahasiswa.unesa.ac.id/index.php/jupe/article/download/2 $3873 / 21816$

[3] Uwes A. Chaeruman. 2017. Pengembangan Model Desain Sistem Pembelajaran Blended Untuk Program Spada Indonesia. Pascasarjana Universitas Negeri Jakarta. https://www.researchgate.net/profile/Uwes_Chaeruman2/publication/ 324390089_Pengembangan_Model_Desain_Sistem_Pembelajaran_B1 ended/links/5acc84720f7e9bcd519b5a72/Pengembangan-ModelDesain-Sistem-Pembelajaran-Blended.pdf

[4] Putro And Jihyun Lee. 2017. Reading Interest In A Digital Age. Routledge: Taylor \& Francis Group. DOI:10.1080/0270271.2017.1341966.

[5] Munir. 2017. Pembelajaran Digital. Bandung Alfabeta.

[6] Extavour \& Gillin. 2018. Students' perceptions of a blended learning pharmacy seminarcourse in a Caribbean school of pharmacy. The University of the West Indies, Tobago \& Trinidad. https://doi.org/10.1016/j.cpt1.2017.12.007

[7] Han \& Robert. 2019. Identifying consistent patterns of quality learning discussions in blended learning. https://doi.org/10.1016/j.iheduc.2018.09.002Get

[8] Borg dan Gall (2010). Educational Research, An Introduction. New York and London. Longman Inc

[9] Arikunto, S. 2010. Prosedur Penelitian Suatu pendekatan praktik. Jakarta : Rineka Cipta.

[10] Usman, Husaini. 2011. Manajemen. Teori, Praktik, dan Riset Pendidikan. Jakarta: Bumi Aksara

[11] Azwar, S. 2010. Sikap Manusia Teori dan Pengukurannya, adisi 2, Yogyakarta : Pustaka Pelajar 
[12] Widoyoko, E. P. (2018). Penilaian Hasil Pembelajaran Di Sekolah. Yogyakarta: Pustaka Pelajar.

[13] Sugiyono. 2018. Metode Penelitian Pendidikan. Bandung : Alfabeta.

[14] Siregar, S. 2014. Statistik Parametrik untuk Penelitian Kuantitatif. Jakarta: Bumi Aksara
[15] Cheung at, all Hew. 2011. Critical Thinking in Asynchronous Online Discussion: An Investigation of Student Facilitation Techniques. National Institute of Education, Singapure.

[16] Dai. 2013. Correlates Of The Reading Interest Of Chinese High School Students In International Schools. Canadian Center Of Science And Education. DOI : 10.5539/ass.v9n3p164. 